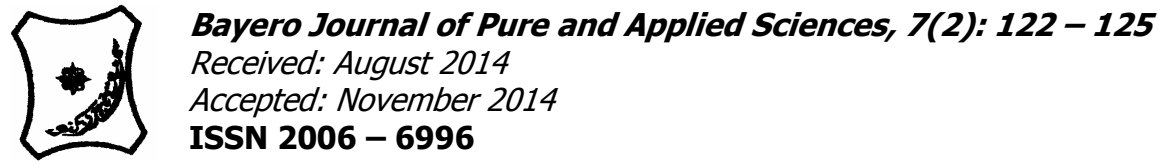

\title{
PHYSICOCHEMICAL, HEAVY METAL AND MINERAL ELEMENTS ASSESSMENT OF WATERS FROM FOUR RIVERS ALONG BENIN-AGBOR ROAD IN EDO STATE, NIGERIA
}

\author{
$*^{1}$ Obahiagbon, F.I. and ${ }^{2}$ Agho, I. \\ ${ }^{1}$ Department of Science Laboratory Technology, University of Benin, Benin City, Edo State, Nigeria \\ ${ }^{2}$ Nigerian Institute for Oil Palm Research, Benin City, Edo State, Nigeria \\ *Correspondence author: fiobahiagbon@yahoo.com
}

\begin{abstract}
The Benin-Agbor road is a major road linking Edo State and the Eastern states of Nigeria, characterized by daily vehicular movements. The inhabitants of the area depend on the river waters mainly for their domestic purposes. It was against the above background that this research was conducted in order to assess the suitability of the waters from four rivers for drinking purposes and the possible hazards the inhabitants may be exposed to. Twenty-two parameters were determined which have relationship with water quality assessment by using recommended methods. Results from the sampling sites indicate that some of the parameters were within the permissible limit recommended by World bodies like the World Health Organization (WHO), whereas other parameters were above the permissible limit like the iron with a range of $2.08 \pm 0.02 \mathrm{mg} / \mathrm{L}$ to 19.90 $\pm 0.20 \mathrm{mg} / \mathrm{L} ;$ manganese $2.20 \pm 0.10 \mathrm{mg} / \mathrm{L}$ to $5.80 \pm 0.20 \mathrm{mg} / \mathrm{L}$ and $/ \mathrm{ead} 0.02 \pm 0.00 \mathrm{mg} / \mathrm{L}$ to $0.17 \pm 0.00 \mathrm{mg} / \mathrm{L}$. The physicochemical parameters like $P^{H}$, colour, electrical conductivity, turbidity, total solids and chemical oxygen demand of the waters of the four rivers ranged between 6.50 \pm 0.10 and $6.30 \pm 0.10 ; 49.70 \pm 0.20$ and18.00 0.00 (Hazen); $80.00 \pm 0.10$ and $19.30 \pm 0.00$ $(\mu / \mathrm{cm}) ; 14.60 \pm 0.20$ and $4.25 \pm 0.20(\mathrm{NTU}) ; 10.50 \pm 0.30$ and4.30 $\pm 0.00(\mathrm{mg} / \mathrm{L}) ; 26.00 \pm 0.00$ and $8.80 \pm 0.20(\mathrm{mg} / \mathrm{L})$ respectively. The continuous ingestion and accumulation of the excess heavy metals like lead whose concentration was higher than the permissible level in drinking water might result in serious health disorders.
\end{abstract}

Keywords: Physicochemical, Anion, Cation, River waters, Edo State

\section{INTRODUCTION}

Water is one of the most important resources in nature. Every living organism depends on water. Water in its pure state is colourless, odourless, sparkling in nature (Egereonu, 2006). The pure water from rains is usually contaminated when it makes contact with the gases in the atmosphere, particles of dust and smoke and when it runs through the ground into the streams, rivers and oceans. Thus, the turbidity, taste and colour would be affected. Additionally, as the rain water moves through the soil, it absorbs $\mathrm{CO}_{2}$ produced by bacterial decomposition of biomass and consequently its $\mathrm{pH}$ is altered (Egereonu, 2004). Moreover, as water flows through the soil several cations and anions being washed away ( such as $\mathrm{Ca}^{2+}, \mathrm{Mg}^{2+}, \mathrm{Na}^{+}, \mathrm{K}^{+}, \mathrm{NH}^{4+}$, which are also balanced by anions such as $\mathrm{SO}_{4}{ }^{2+}, \mathrm{NO}^{2-}, \mathrm{Cl}^{-}$and $\mathrm{NO}^{3-}$ ). The $\mathrm{pH}$ of river water varies depending on its location and the dissolved substances (Obahiagbon et al., 2008).Mineral elements cannot be synthesized by living organisms but they are required daily in human diet to meet the Recommended Dietary Intakes (NAS, 2001). The Recommended Dietary Intakes for nutrients like mineral elements, for optimum nutrition in infants, children, adults and pregnant women, depend on doses, size, lactation and sex (Obahiagbon et al., 2008).Amongst other functions, mineral elements function as structural components of body organs, and tissues, constituents of body fluids and hormonal system. Additionally, the functional roles of mineral elements in the human body are interrelated and balanced against each other, and most often cannot be considered as single elements with independent and self-sufficient roles in the organized bodily processes (McDowell, 1992). World health bodies have set several standards and analytical procedures for drinking water, which serves as a guide for the toxicity levels of water components (WHO, 1984; F.E.P.A., 1991; and A.P.H.A., 1995).The rural dwellers where the rivers are located along Benin-Agbor road depend on rain water, and the rivers for their domestic and other uses. These rivers are exposed to all kinds of contamination from the swimming and washing of dirty clothes by the inhabitants of the area. Thousands of vehicles which pass through this busy road linking Edo state and the Eastern States of Nigeria discharge their vehicular wastes into these rivers daily. In view of these, this paper is examining the physicochemical contaminants, heavy metals and mineral elements in the rivers and possible health hazards to the occupants of the area. It is therefore hoped that the result generated from these studies would be of immense help to the public.

\section{MATERIALS AND METHODS}

Sampling Sites

The points at which the inhabitants fetched drinking water were chosen as the collection points for the samples obtained from the rivers. The rivers were located along Benin-Agbor road in Edo State. 
Bajopas Volume 7 Number 2 December, 2014

The Benin-Agbor road is a major high-way which links Edo State to the Eastern states of Nigeria. Thousands of vehicles use this route on a daily basis. The rivers sampled were: Ikpoba, Okhuahe, Ugonoba and Abudu in Ikpoba Okha Local government area. The sampling was done on forth nightly basis for a period of four months during the rainy season (that is, between April and July, 2012).

\section{Collection of Water samples}

The water samples were collected in polyethylene bottles $(250 \mathrm{ml})$ previously washed and rinsed with deionized water.

The physicochemical parameters determined were as follows:

$\mathbf{P}^{\mathbf{H}}$. This was determined at the sites of collection of the water samples with an electronic pocket $\mathrm{pH}$ meter, Jenway 430 (Bates, 1973).

Electrical Conductivity. The electrical conductivity (EC) was measured at the sites of the collection of water samples with an EC meter (Jenway 4200).

Colour. The colour of the waters was determined with a Lovibond Comparator in Hazen Units.

Turbidity. The Franson (1975) method was adopted for the determination of turbidity.

Total Solids. The evaporation and weighing method was used for the determination of the total dissolved solids in the waters (IITA, 1970).

Chemical Oxygen Demand (B.O.D.). The method described by Ademoroti(1996) was used for the BOD determination.

Sodium, Potassium and Calcium. The method described by Willard et al. (1981) was used for the determination of these elements with a flame photometer.

Heavy metals and Mineral elements. $5 \mathrm{ml}$ each of the water samples was digested with $5 \mathrm{ml}$ concentrated nitric acid and $3 \mathrm{ml}$ hydrogen peroxide and heated on a hot plate inside a fume cupboard for 2 hour. The solution was made up to $5 \mathrm{ml}$ in a volumetric flask. Thereafter, the aborption of the aliquots were read with an Atomic Absorption Spectrophotometer, Unican Series, Model 969, for the determination of the following in the waters: Magnesium, Chloride, Iron, Manganese, Zinc, Copper, Chromium, Nickel, Lead and Valedium(Willard et al.,1981).

Nitrite, Nitrate and Sulphate. These were determined in the water samples by the methods described by Harrison and Perry (1986).

\section{RESULTS AND DISCUSSION}

The results of the physicochemical parameters, heavy metals and mineral elements determined in the waters of the four rivers are presented in Tables 1 and 2 respectively. The trends observed in the results of the river waters were that irrespective of the location of the rivers, the parameters detected varied. Deviations from the above trend were observed in the values obtained for $\mathrm{pH}$ and chromium which were at close ranges. The $\mathrm{pH}$ is one of the important water quality parameters, which affects the biochemical process in water (Chapman, 1996). The mean pH range of the four rivers was between $6.30 \pm 0.10$ and $6.50 \pm 0.10$. In other words, the $\mathrm{pH}$ of the four rivers was slightly acidic. Overall, the $\mathrm{pH}$ of the four rivers were within the permissible limit recommended (6.50 - 8.50) by WHO (1993) for drinking water. The results further indicate that. since the $\mathrm{pH}$ values are not low, much of carbon dioxide arising from bacterial decomposition of organic matter was not dissolved in them but may be due to the release from the microscopic plant in the rivers. The near neutral $\mathrm{pH}$ values obtained may be attributed to the equilibrium state the system attempted to attain (Chebotarey, 1955).

The colour parameters of the waters from the four rivers were low and ranged between $18.00 \pm 0.00$ and $49.70 \pm 0.20$ (Hazen). The colour of river water is usually due to the presence of substances like organic matter which modifies the water to green, straw yellow, or brown. It is the presence of this colour that is measured in water to determine its purity (Ademoroti, 1996).

The electrical conductivity of the waters from the four rivers ranged between $33.30 \pm 0.10$ and $119.30 \pm 0.00 \mu \mathrm{s} / \mathrm{cm}$. The Ikpoba river had the highest electrical conductivity reading because of the dissolved ionic components in its water. The electrical conductivity value recommended by WHO (1993) in drinking water is $14.00 \mu \mathrm{s} / \mathrm{cm}$. The values obtained from the river waters could be said to be high and may have resulted from dissolved mineral matters.

The turbidity values for the four river waters ranged between $4.25 \pm 0.20$ and $14.60 \pm 0.20$ NTU. The low levels of the turbidity values detected in the waters might be an indication that low levels of clay, mud, organic matter, bacteria and algae were present. It has been reported that higher turbidity levels are often associated with higher levels of disease-causing microorganisms such as viruses, parasites and some bacteria and as a consequence, domestic/drinking water should have low turbidity level since suspended particulates provides suitable sites for the growth of bacteria and other microorganisms which have health risk(A.P.H.A, 1995) .

The mean values of the total solids of the four river waters ranged between $4.30 \pm 0.20$ and $10.50 \pm 0.30 \mathrm{mg} / \mathrm{L}$. These values appear low when compared with the WHO (1984) recommended $100 \mathrm{mg} / \mathrm{L}$ permissible level in drinking water. The total dissolved solids (TDS) is usually due to dissolved carbonates, chlorides, sulphates, calcium, magnesium, potassium, dissolved metals, dissolved organics etc.

The mean value of the chemical oxygen demand of the four waters ranged between $8.80 \pm 2.20$ and $27.80 \pm 0.30 \mathrm{mg} / \mathrm{L}$. The permissible concentration of Chemical Oxygen Demand (COD) in drinking water is $80.01 \mathrm{mg} / \mathrm{L}$ (WHO, 1984). The low concentration of COD in Ikpoba river suggest that the microorganisms in the river would require less oxygen for the biodegradation of organic matters or that there is low level of microorganisms in the river. 
The mean value of sodium detected in the sampling sites of the four rivers ranged between $0.70 \pm 0.00$ and $0.90 \pm 0.10 \mathrm{mg} / \mathrm{L}$. These values are far below the permissible $200 \mathrm{mg} / \mathrm{L}$ recommended for drinking water (WHO, 1984).

The anion components (chloride, sulphate, nitrate, nitrite) mean concentrations at the sampling sites of the four rivers appear low relative to the maximum concentrations permissible in drinking water. The permissible concentration for chloride, sulphate and nitrate are $250 \mathrm{mg} / \mathrm{L}, 25 \mathrm{mg} / \mathrm{L}$, and $45 \mathrm{mg} / \mathrm{L}$ respectively (WHO, 1984).

The cation concentrations at the sampling sites (copper, chromium, nickel, valedium, calcium, potassium and sodium) were lower than the WHO (1984) permissible levels in drinking water, except the concentrations of iron, manganese, and lead which were higher. The values recommended for drinking water for iron, manganese, and lead are $0.3 \mathrm{mg} / \mathrm{L}$,
$0.05 \mathrm{mg} / \mathrm{L}$ and zero respectively. These results might be attributed to the geology of the areas, which could probably be the source of iron (Amadi and Morrison, 2001). Additionally, the higher concentrations of iron detected in the waters are capable of damaging fabrics, paper and corrode the inner walls of high pressure boilers. The higher concentrations of manganese in the waters is capable of causing health disorders associated with severe psychiatry (Locura Marganica) resembling schizophrenia, followed by permanent crippling neurological disorder, clinically similar to Parkinson's disease (Klanssen, 2004). The high concentrations of lead detected in the waters are capable of causing severe health hazards being a toxic element. The above concentrations of lead in the river waters might have resulted from the exhaust discharge of the vehicles that passes through the road daily.

Table 1: Physicochemical analysis of Waters from Four Rivers along Benin- Agbor Road (Mean of April - July, 2013)

\begin{tabular}{|c|c|c|c|c|c|}
\hline $\mathbf{S} / \mathbf{N}$ & Parameters determined & Ikpoba & Okhuahe & Ugonoba & Abudu \\
\hline 1 & $\mathrm{P}^{\mathrm{H}}$ & $6.40 \pm 0.00$ & $6.50 \pm 0.10$ & $6.30 \pm 0.10$ & $6.30 \pm 0.10$ \\
\hline 2 & Colour (Hazen) & $49.70 \pm 0.20$ & $42.20 \pm 0.10$ & $18.00 \pm 0.00$ & $46.70 \pm 0.20$ \\
\hline 3 & $\begin{array}{l}\text { Electrical } \\
(\mu \mathrm{s} / \mathrm{cm})\end{array}$ & $80.00 \pm 0.10$ & $47.00 \pm 0.00$ & $33.30 \pm 0.10$ & $19.30 \pm 0.00$ \\
\hline 4 & Turbidity (NTU) & $14.60 \pm 0.20$ & $10.70 \pm 0.10$ & $4.25 \pm 0.20$ & $12.50 \pm 0.10$ \\
\hline 5 & Total solids (mg/L) & $10.50 \pm 0.30$ & $7.70 \pm 0.20$ & $4.30 \pm 0.00$ & $9.60 \pm 0.10$ \\
\hline 6 & $\begin{array}{l}\text { ChemicalOxygen Demand } \\
(\mathrm{mg} / \mathrm{L})\end{array}$ & $26.00 \pm 0.00$ & $21.40 \pm 0.10$ & $8.80 \pm 0.20$ & $27.80 \pm 0.30$ \\
\hline
\end{tabular}

Table 2. Heavy Metals and Mineral Elements of Four Rivers along Benin-Agbor Road (Mean of AprilJuly 2013)

\begin{tabular}{llllll}
\hline S/N & Parameters & Ikpoba & Okhuahe & Ugonoba & Abudu \\
& Determined & & & & \\
1 & & & & & \\
2 & Sodium (mg/L) & $1.40 \pm 0.00$ & $0.90 \pm 0.10$ & $0.72 \pm 0.00$ & $1.86 \pm 0.10$ \\
3 & Catassium (mg/L) & $0.64 \pm 0.01$ & $0.35 \pm 0.00$ & $0.23 \pm 0.00$ & $1.81 \pm 0.01$ \\
4 & Magnesium (mg/L) & $0.45 \pm 0.00$ & $0.79 \pm 0.02$ & $0.19 \pm 0.00$ & $2.22 \pm 0.01$ \\
5 & Chloride (mg/L) & $0.14 \pm 0.00$ & $0.09 \pm 0.00$ & $0.38 \pm 0.01$ & $2.14 \pm 0.01$ \\
6 & Iron (mg/L) & $0.12 \pm 0.00$ & $0.08 \pm 0.00$ & $0.68 \pm 0.02$ & $1.21 \pm 0.10$ \\
7 & Manganese (mg/L) & $11.20 \pm 0.00$ & $9.40 \pm 0.00$ & $2.80 \pm 0.20$ & $1.21 \pm 0.10$ \\
8 & Zinc (mg/L) & $2.68 \pm 0.10$ & $2.20 \pm 0.10$ & $0.39 \pm 0.00$ & $5.80 \pm 0.20$ \\
9 & Copper (mg/L) & $0.05 \pm 0.00$ & $0.07 \pm 0.00$ & $0.19 \pm 0.01$ & $0.09 \pm 0.00$ \\
10 & Chromium (mg/L) & $0.04 \pm 0.00$ & $0.04 \pm 0.00$ & $0.04 \pm 0.00$ & $0.05 \pm 0.00$ \\
11 & Nickel (mg/L) & $0.04 \pm 0.00$ & $0.03 \pm 0.00$ & $0.03 \pm 0.00$ & $0.03 \pm 0.00$ \\
12 & Lead (mg/L) & $0.05 \pm 0.01$ & $0.02 \pm 0.00$ & $0.01 \pm 0.00$ & $0.02 \pm 0.00$ \\
13 & Valadium (mg/L) & $0.08 \pm 0.01$ & $0.17 \pm 0.00$ & $0.02 \pm 0.00$ & $0.06 \pm 0.00$ \\
14 & Nitrite (mg/L) & $0.03 \pm 0.00$ & $0.04 \pm 0.00$ & $0.01 \pm 0.00$ & $0.03 \pm 0.00$ \\
15 & Nitrate (mg/L) & $0.54 \pm 0.01$ & $0.37 \pm 0.02$ & $0.09 \pm 0.00$ & $0.34 \pm 0.01$ \\
16 & Sulphate (mg/L) & $1.01 \pm 0.00$ & $0.82 \pm 0.02$ & $0.19 \pm 0.03$ & $0.88 \pm 0.02$ \\
\hline
\end{tabular}

\section{CONCLUSION}

The physicochemical characteristics, heavy metals and mineral elements assessment have shown that the parameters detected varies from one sampling site of the rivers to the other and in some cases the parameters of the river waters were at close range. The concentrations of the cation components of the river waters, and some heavy metals were observed to be higher than the permissible level in drinking water while the anion components were lower than the permissible level in drinking water. However, the continuous ingestion of the cations whose levels were higher than the permissible levels in drinking water could result in serious health disorders. 


\section{REFERENCES}

A.P.H.A. (1995). Standard Methods for the Examination of Water and Wastewater $19^{\text {th }}$ Ed. American Public Health Association.

Ademoroti, C. M. A. (1996). Standard Methods for Water and Effluents Analysis, March Prints and Consultancy, $1^{\text {st }}$ Ed, pp 23-28.

Amadi, P.A.C.O. and T. Morrison (2001). "Hydrogeochemical assessment of groundwater quality in parts of Niger Delta" Nig. Environ. Geo. Water Sci. 14(3):195-202..

Bates, R.G. (1973). Determination of $P^{H} .2^{\text {nd }}$ Ed., Wiley, New York. pp. 245-278

Chapman, D. (1996). Water Quality Assessment. A Guide to the use of Biotic Sediments and Water in Environmental Monitoring $2^{\text {nd }}$ ed. Chapman and Hall, London.

Chebotarey, A. (1955). "Metamorphism of Natural Waters on the Crust of weathering" GEOCHEMET Costmechi Acta. 8: 22-48.

Egereonu, U.U and D. Emezian (2006). Physicochemical Analysis of Selected Groundwater in Rivers State, Nigeria to Ascertain Pollution Level, Encrustation and Corrosion Potentials, J. Chem. Society of Nigeria (1\&2) : 168-175.

Egereonu,U.U.(2004). Groundwater Quality Measures, Aba and Mbaise and their Environments in South Eastern Nigeria, J. AMSE, 65(3), 44-53.

F.E.P.A. (1991). Guideline and Standards for Environmental/Pollution Control in Nigeria.
Franson, M.A. (Ed). (1975). Standard Methods for the Examination of Wastewater, $14^{\text {th }}$ Ed., APHAAWWA-NY. pp.159, 163, 235 and 252.

I.I.T.A. (1970). Selected Methods of Soil and Plant Analysis, International Institute for Tropical Agriculture, Ibadan, pp.6-7.

Klaassen, C.D. (2004). Heavy Metals and Heavy Metals Antagonists. In Hardman et al. (Ed). The Pharmaceutical Basis of therapeutics, McGraw Hill New York, pp. 1851-1875.

McDowell, L.R. (1992). Minerals in Animal and Human Nutrition, Academic press Inc. New York. pp. $26-294$

NAS (2001). Dietary Reference Intakes for Vitamins and Mineral Elements, National Academy Press, 773p, Washington, D.G.

Obahiagbon, F. I., E. G. Uwumarongie and G.E. Ikuenobe (2008). Physicochemical Examination of Rain and River waters Collected at the Nigerian Institute for Oil Palm Research, Benin City. ChemTech Journal, 4: 38- 42.

WHO (1984). Guidelines for Drinking water quality.Vol. 1, 4th Ed. Geneva.

WHO (1993). GEMS/Water Operational Guide. $3^{\text {rd }}$ Ed. World Health Organization, Geneva.

Willard, H.W., Maritt, L. L., Dean, J.A. and Settle, F.A.(1981). Instrumental Methods of Analysis, $6^{\text {th }}$ Ed. D. Van Nastrand Company, New York.pp127-129. 